\title{
Fashion Education Students' Achievement on Entrepreneurship Lecture Uses Blended Learning in the Pandemic Period
}

\author{
Sicilia Sawitri ${ }^{1}$, Rina Rachmawati ${ }^{2}$ \\ \{sicilia.sawitri@mail.unnes.ac.id\} \\ Home Economic Department, Universitas Negeri Semarang, Indonesia ${ }^{12}$
}

\begin{abstract}
Nowadays we are in the pandemic period, everything changed. The teaching and learning process had changed, from luring to daring. The study aims to know the achievements of the Fashion Education Study Program students in Entrepreneur lecture used blended learning during the pandemic period. The research method was survey on Entrepreneur instructional achievements of student on Entrepreneur lecture. The data were analyzed using percentage descriptive technique. The result, there was a good students' achievement it was about $79 \%$ on Entrepreneur lecture by applying blended learning during pandemic period.
\end{abstract}

Keywords: Fashion Education; Entrepreneurship; Blended Learning; Pandemic

\section{Introduction}

Fashion Education Study Program is one of some study programs in Engineering Faculty. Fashion Education Study Program produce graduates who can work in vocational school as a teacher, a fashion designer, and as fashion entrepreneur. The business of entrepreneur in fashion are haute couture, pret-a-porte (ready-to wear), and pre-a-couture [1]. Become an entrepreneur takes a variety of skills, and entrepreneur spirit. Fashion Education Study Program students besides study about fashion they also learn about entrepreneurship. The Entrepreneurship course discusses the concept of entrepreneur, technopreneur, spirit, characteristic, analysis of costs and risks on a business as well as entrepreneurial competence. The delivery technique on instructional processes of Entrepreneur lecture is direct instruction, learning assignments, discussion, survey to the small and medium enterprise.

Since March, 2020, as long as there is Covid-19 pandemic has changed various aspects of human life, such as in education [2]. The instructional process was changed. Before the pandemic period, the instructional process was in campus, but most of the academic community work from home, but the learning must continue. There are some ways to handle this case. One is applying blended learning in the instructional process. Entrepreneurship is a creative and innovative ability (create new and different) that used as tips, basic, resource, process and struggle to create value-added goods and services with the courage to face the risk. Entrepreneurship is the practice of creating value by identifying business opportunities, managing risk-taking opportunities and skills through communication and mobilizing human, so that the plan can be well done. Drucker cited [3] argued that, entrepreneurship is the ability to create something new and different. 
Entrepreneurship comes from the French word entreprenerd which means responsibility. Entrepreneur is people who is responsible in preparing, managing, and measuring the risks of business, while entrepreneurship according [4] is:" Entrepreneurial is the process of creating something new with value by devoting the necessary time and effort, assuming the accompanying financial, psychic, and social risk, and receiving the resulting rewards of monetary and personal satisfaction in independence". Some experts argued about the different characteristics of entrepreneur. Entrepreneur characteristics according [5], are: 1) pursue achievement, 2) willing to take risks, 3) able to solve problems, 4) humility, 5) excited, 6) confidence, 7) avoid the maudlin character, and 8) looking for self-satisfaction. But others argue that entrepreneur characteristics are: 1) self-confidence, 2) task and result-oriented, 3) risk taker, 4) leadership, 5) originality, and 6) future oriented [6]. The opinions of [3] about the characteristics of entrepreneur, are: (1) have a clear vision and mission, (2) initiatives, (3) achievement-oriented, (4) dare to take a risk, (5) hard work, (6) responsible, (7) the commitment, and (8) develop and maintain good relationships with various parties.

From some opinions above, it can be concluded that the characteristics of entrepreneur are: confident, willing to take the risk, having a spirit of leadership, creative, innovative, attitude towards change, working smart, forward vision, and, originality (always creating something new and original), initiative, have strong intuition, have mental freedom, and social rebels. Some internal sources that can be found in each entrepreneur are: entrepreneurship interest, motivation, creativity in entrepreneurship, skills, communication skill, and leadership. Besides of internal sources of entrepreneurship, there are some external sources include family environment, society and type of business in fashion. Interest tends to be relatively permanent on specific subject, feels interested in certain field, and feels happy to dive into that field. This argument suggested that interest is tendentious statement about the activities that are usually done day by day, it leads to love the activity Nunally, cited by [7]. The interest is human kind activities in learning and freely choose what is preferred; interest is always related to individual skills, needs, and experiences [8].

Characteristic properties that students need to have if they want to be entrepreneur are closely related to the need to express themselves in developing innovation values in order to obtain the much more promising business changes [7]. Those characteristic properties include: (1) perseverance to do and finish the tasks, (2) having a courage to take risks to the tasks performed, (3) future-oriented, (4) reference to the achievement of success with calculated risks (moderate risk), (5) tendency to reach a higher position (upward mobility), (6) the willingness to complete unfinished works and/or failed to do before, (7) dynamic, i.e. consider that the time is always limited and go fast (time perspective), (8) selecting peer work based on skills and abilities, (9) the desire to gain recognition of their work, and (10) a behavior that always want to be excellent.

Entrepreneurship Creativity originally has been possessed by every individual born, although, with different levels. Creativity form dimension of Press. Amabile cited by [9], suggested that: Creativity can be regarded as the quality of product responses are judged to be creative by appropriate observes. Guilford cited [10] with his factor analysis found five characteristics that inherent the ability to think: First, fluency is the ability to produce a lot of ideas. Second, flexibility is the ability to apply a variety of approaches and/or solutions to the problem. Third, originality is the ability to initiate to original ideas as his/her own and not cliché ideas. Fourth, the elaboration refers to the ability to explain something in detail.

Creativity in entrepreneurship can be demonstrated by the students' ability to manage a fashion business; making a new variety of fashion products and household linen by utilizing the old stuffs. The originality of an entrepreneur is characterized by the creation of new 
products using the stuffs that have already existed. The students, for example, can create a product of cover for a tissue box by utilizing patchworks, making picture frames from recycled paper, and other new products that are simple but a creation of students themselves. The achievements of students on Entrepreneur subject are depending on the instructional model. The course materials in Entrepreneur Lecture are concept of entrepreneur, technopreneur, spirit, characteristic, analysis of costs and risks on a business which deliver by using blended learning. At the first semester, the lectures conducted in class, face to face between lecturer and students.

The students' achievement on Entrepreneur Lectures is depending on the instructional model. Since pandemic period the lecturer must change the instructional model. One of the models which can be applied in the pandemic is blende Learning. Blended learning according Friesen cited by [11], mean that there are combination of technologies, pedagogies and job tasks. It means it can be interpreted that the three components are related to one another. Blended learning also defined the effective combination of different modes of delivery, teaching models, and learning style (Procter cited [11]. Blended learning (BL), mean that there is integration of classroom face-to-face learning experiences with on line learning experiences (Garrison cited by [12].

Blended learning based on constructivism theory which characterize individual learning and blended e-learning Hasibuan cited by [13]. Blended learning forms of direct and indirect online learning, of course it is usually involving the internet [14]. The greatest advantage of blended learning, according [15], is that having considerable part of the course online enables us to extend the period of learning over far greater timescale than with face-to-face teaching. Blended learning on Entrepreneur Lecture,[16], access to a wide choice of alternative resources on the personal computer, the teaching materials upload in the e-learning system, all of the students got the material and assignment. Then studying online with tutors as facilitators and emphasis on co-creation within a course that is rich in on-line collaboration, in this period the students can discuss themselves.

\section{Methodology}

The research was conducted at Fashion Education, Engineering Faculty, Universitas Negeri Semarang, in March - June 2020. The method used in this research was survey on Fashion Education Study Program. The population was the students in Fashion Education Study Program and the samples were the students who attended the Entrepreneur lecturer, second semester students of Fashion Education Study Program, about 83 Persons, consist of two classes. The data collection used learning outcomes instrument, consisting of daily exams, midterm exams and final semester exams. The data was taking from the assessment list. The data were analyzed using the percentage descriptive technique.

\section{Result and Discussion}

The result of the research, the students' achievement on Entrepreneur lecture was $79 \%$, it was high category. The highest score was 87 and the lowest score was 72 . On online lectures, the material can still be understood, because there often discussion in the google classroom. The current online learning model, there some students who accept the model of 
teaching, because the online learning more relaxed, fun, flexible, efficient, short time, practical, fast, precise, safe, easy, time saving and energy-saving, without gathering in the same place. Even the achievement was high, but it was not optimal. Some reason why the achievement was not optimal, sometimes the signal did not run well, sometimes the Another obstacle, there is still miscommunication. Sometimes what was explained by lecturer is misunderstood by students. The students must learn independently without collaboration in an open environment.

\section{Conclusion}

The achievement of students of Fashion Education Study Program, after they attended the Entrepreneur Lecture was high. It can be higher than now, if the instructional facility for daring complete, such as internet, good signal, lecturer always gives feed back to the students' assignment.

\section{References}

[1] Tian, B. Hu, S. (2016). The Application of Creative Design in Apparel Industry. Art and Design Review, Scientific Research Publishing (15-9-2016).

[2] Herliandry, LD, Nurhasana, Suhan, ME, Kuswanto, H, (2020). Pembelajaran Pada Masa Pandemi Covid-19. Jurnal Teknologi Pendidikan, Vol. 22, No. 1, April 2020 (http://journal.unj.ac.id/unj/inde.php/jtp)

[3] Kasmir, (2011). Kewirausahaan. Jakarta: PT Raja Grafindo Persada

[4] Hisrich, RD dan Peter, MP. Shepherd. (2008).Entrepreuneurship.Boston: Irwin McGraw Hill.

[5] Machfoedz, M. Machtoedz, M.2004. Kewirausahaan Suatu Pendekatan Kontemporer. Yogyakarta: UPP AMP YKPN

[6] Alma, B. (2001). Kewirausahaan Penuntun Perkuliahan untuk Perguruan Tinggi. Bandung: Alfabeta

[7] Sintawati, E.. 2009. Menumbuhkan Minat Berwirausaha Mahasiswa Tata Busana Melaui Pembelajaran Kewirausahaan. Makalah Seminar NasionaldanGelarKarya, "Smart, Healthy and Beauty" Surabaya: UNESA 6 Juni 2009

[8] Hurlock, E.E. (1981). Child Development. Tokyo: McGraw-Hill Kogakusha Ltd.

[9] Hawadi, RA, Wihardjo RSD, Wiyono, M, (2001). Kreativitas. Jakarta: Garsindo

[10] Dembo, MH. (1981). Teaching for Learning Apllying Educational Psychology in the Classroom. Santa Monica, California: Coodyear Publishing Company. Inc

[11] Bryan, A. and Volchenkova, KN, (2016). Blended Learning: Definiton, Models, Implications for Higher Education. Bulletin of the South Ural State University, Vol 8, no 2, pp 24-30

[12] Hade, S. (2014). Strenght Weaknesses Opportunities and Threat of Blended Learning: Students' perception. Annals of Medical and Health Science Research Vol. 4. Isue 3 May-June 2014).

[13] Sukoco, PC. (......). Blended Learning dalam Pembelajaran. Prosiding Seminar Nasional Profesionalisme Tenaga Profesi PJOK Universitas Negeri Malang

[14] Oweis, TI. (2018). Effects of Using a Blended Learning Method on Students' Achievement and Motivation to learn English in Jordan: A Pilot Case Study. Hisdawi: Education Research International, Volume 2018.

[15] Peachy, N. (2013). A Blended Learning Teacher Development Course For The Development Of Blended Learning In English Language Teaching. in Blended Learning in English Language Teaching: Course Design and Implementation. London: British Council

[16] Littlejohn, A, Pegler, C. (2007). Preparing for Blended e-Learning. London and New York: Routledge. 